\title{
Depositional environments of the Carboniferous-Permian Taiyuan Formation (southern North China Block) as deduced from trace elements and from carbon and oxygen isotopes
}

\author{
Dawei $\mathrm{LV}^{1,2}$, Guangqing $\mathrm{HU}^{3,4}$, A.J. (Tom) VAN LOON ${ }^{5, *}$ and Dun $\mathrm{WU}^{3,4}$ \\ 1 Shandong University of Science and Technology, Shandong Provincial Key Laboratory of Depositional Mineralization and \\ Sedimentary Minerals, Qingdao, Shandong 266590, China \\ 2 Laboratory for Marine Mineral Resources, Qingdao National Laboratory for Marine Science and Technology, Qingdao, \\ Shandong 266237, China \\ 3 University of Science and Technology of China, School of Earth and Space Sciences, Hefei, Anhui 230026, China \\ 4 Exploration and Research Institute, Anhui Provincial Bureau of Coal Geology, Hefei 230088, China \\ 5 Shandong University of Science and Technology, College of Earth Science and Engineering, Qingdao, Shandong \\ 266590, China
}

Lv, D., Hu, G., Van Loon A.J. (Tom), Wu, D., 2021. Depositional environments of the Carboniferous-Permian Taiyuan Formation (southern North China Block) as deduced from trace elements and from carbon and oxygen isotopes. Geological Quarterly, 2021, 65: 1, doi: 10.7306/gq.1570

\begin{abstract}
Limestone layers are extensively developed in the continental/ocean transitional Taiyuan Formation. This formation accumulated on the southern North China Block. The precise environmental conditions of the Taiyuan Formation are still controversial. More information about these topics is presented here on the basis of the analysis of trace elements (Mo, $\mathrm{V}, \mathrm{Cd}, \mathrm{Cr}$, $\mathrm{U}, \mathrm{Th})$, which can be used to determine characteristics of the depositional environment, and of carbon and oxygen isotopes $\left(\delta^{13} \mathrm{C}\right.$ and $\left.\delta^{18} \mathrm{O}\right)$ in limestone samples from the Huainan Coal Basin. Samples were taken for the purpose from cores of all 13 limestone levels, obtained from a coal-exploration borehole (code P2) in the Huainan Coal Basin. It was found that the $\delta^{18} \mathrm{O}$ values show a decreasing trend, suggesting a gradual rise of the sea level in a warm climate. Three negative shifts of $\delta^{13} \mathrm{C}$ appear in a lower, a middle and an upper limestone layer, accompanied by relative enrichment of the redox-sensitive elements $(\mathrm{Cd}, \mathrm{Cr}$, Mo and $\mathrm{V})$. These three layers are thus deduced to have been deposited in a warm climate with a high sea level and with more terrigenous input than during deposition of the other limestone layers. The redox elements and elemental ratios $(\mathrm{V} / \mathrm{Cr}$, Th/U) in the limestones suggest deposition in an oxygen-rich sea with high salinity.
\end{abstract}

Key words: Taiyuan Formation, North China Block, palaeoenvironmental reconstruction, trace-element analysis.

\section{INTRODUCTION}

The Carboniferous-Permian transition is an important time-span because the Earth changed from a greenhouse to an icehouse, and experienced intensive glacio-eustatic fluctuations (e.g., Bruckschen et al., 1999; Golonka and Ford, 2000; Sahney et al., 2010; Montańez and Cecil, 2013). Moreover, the Pangea supercontinent was formed by collision of several plates (Isbell et al., 2008). Coal-bearing successions developed in the low-latitude areas (among which the North China Block) on the continents, whereas the characteristics of the oceans (e.g., Eh, salinity, detrital input and life forms) became more dif-

* Corresponding author, e-mail: Geocom.VanLoon@gmail.com Received: July 20, 2020; accepted: October 12, 2020; first published online: December 13, 2020 ferentiated due to the global changes in palaeoclimate (Scheffler et al., 2003).

The North China Block (NCB) was during the Carboniferous situated at the eastern margin of the Palaeotethys Ocean, on both sides of the equator (Golonka and Ford, 2000; Zheng et al., 2013). At the end of the Carboniferous, an epicontinental sea existed on the NCB, in which the Taiyuan Formation accumulated. This continued till in the Early Permian ( $L v$ and Chen, 2014). Successive transgressions and regressions that occurred while the formation was building up resulted in a succession with alternating limestones, coals and clastic sediments.

Marine sedimentary successions on the NCB preserved, like such successions elsewhere in the world, changes in the characteristics of the sea water, particularly its geochemistry. This implies that analysis of these sediments can help reconstructing the oceanic development if the right clues are found. Is has become clear that particularly the isotope and element compositions of marine carbonates tend to reflect the original geochemical signature of the ocean, and that the isotope and element compositions are controlled by factors such as the in- 
put of terrigenous material, the solubility of the elements, and the Eh of the sea water (Wignall et al., 2007). Regarding the first aspect, weathering of the continental crust is the main process releasing elements that eventually reach the ocean, while the second aspect, i.e. the solubility of elements in the sea water, largely depends on the characteristics of the elements and the redox potential of the water. Insoluble elements, such as Al, Sc, $\mathrm{Hf}$, Th and REE, tend to become incorporated in carbonates along with particles, forming impure carbonates (Frimmel, 2009; Zhao et al., 2009). In contrast, easily dissolved elements such as $\mathrm{Na}, \mathrm{Mg}$ and $\mathrm{U}$ are incorporated as ions in the crystal lattice of the carbonates, forming pure carbonates. Analysis of the element composition of marine carbonates is consequently widely applied for the reconstruction of the palaeoenvironments of the ocean.

The carbon and oxygen isotope anomalies (denoted as $\delta^{13} \mathrm{C}$ and $\left.\delta^{18} \mathrm{O}\right)$ in carbonates also depend on the depositional environment. The $\delta^{13} \mathrm{C}$ and $\delta^{18} \mathrm{O}$ values are important geochemical tools for studying not only the depositional environment (Pufahl et al., 2006; Payne and Kump, 2007) but also the palaeoclimate (Kaufman et al., 1993; Kump and Arthur, 1999; Korte et al., 2005). They have also widely been used in unraveling the global carbon cycle, glacial/interglacial cycles, biological footprints, temperature and sea level fluctuations, and the evolution of the sea water (Scheffler et al., 2003; Jaffrés et al., 2007; Veizer and Prokoph, 2015). The positive and negative excursions of $\delta^{13} \mathrm{C}$ and $\delta^{18} \mathrm{O}$ in carbonates are commonly linked to important global events. For example, Bruckschen et al. (1999) showed that the overall 3-4\%o increase of $\delta^{13} \mathrm{C}$ with $\delta^{18} \mathrm{O}$ in Carboniferous brachiopods is related to the transition from the Tournaisian greenhouse to the Gzhelian icehouse.

\section{OBJECTIVES OF THE STUDY}

Several studies have been devoted to the development in present-day China of the Carboniferous and Permian development in the Palaeotethys Ocean (e.g., Lee and Lee, 2003; Lv and Chen, 2014), often with a focus on the palaeontology (Tazawa, 2002), the provenance of the clastics (Li et al., 2010; Zhang et al., 2014) and the stratigraphy (Han, 1990; Shao et al., 2015) which is partly based on the presence of volcanic tuff layers (Schmitz et al., 2020), but the depositional environments of the epicontinental sea in which the Taiyuan Formation accumulated are still a matter of debate (Guo and Liu, 2000; Li and Wang, 2006; Song et al., 2011), mainly because interpretations of the fossils, which may partly have been washed in, are mutually inconsistent (Song et al., 2015; Mao et al., 2018; Wang et al., 2019). The most important groups of fossils found in the Taiyuan Formation are plants, brachiopods, gastropods, corals, crinoids, fusulinids and ostracods (Ge et al., 1985; Gao, 1988; Fan et al., 1999; Wan et al., 2017; Zhang, 2017). The origin of the fossils (more or less in place or washed in from far away) is also a point of discussion, because some studies state that the limestones were formed in an oxidizing environment (e.g., Guo and Liu, 2000), whereas other studies mention a reducing environment (e.g., Song et al., 2011).

The objective of the present contribution is therefore to shed more light on the depositional conditions. For the purpose, the characteristics of the sea water were investigated by means of analyses of the isotope anomalies $\left(\delta^{13} \mathrm{C}\right.$ and $\left.\delta^{18} \mathrm{O}\right)$ and the trace elements in the sediments. Such a study has not been carried out earlier for this formation.

\section{GEOLOGICAL SETTING}

During the Late Carboniferous, the North China Block had reached a position at the eastern end of the Palaeotethys Ocean, forming the border with Panthalassa at its eastern side (Fig. 1A). It did not belong to the supercontinent Pangea (Golonka and Ford, 2000; Shen et al., 2006). The NCB experienced uplift during the Middle Ordovician Caledonian orogenesis, exposing the sediments of the NCB to long-lived denudation until the Late Carboniferous. As a result, the Middle Ordovician to Upper Carboniferous succession is no longer present, and the boundary between the Middle Ordovician and the Upper Carboniferous is an unconformity.

From the Late Carboniferous to the Early Permian, numerous layers of marine limestone were deposited (Wu et al., 1995) (Fig. 1B). The present contribution focuses on a limestone succession in the Huainan Coal Basin (HCB; Fig. 1C), deposited around the transition from the Carboniferous to the Permian; the precise age is still a matter of debate. These sediments were deposited in a cratonic basin, at the southeastern margin of the NCB.

During the Late Carboniferous, the HCB started subsiding, resulting in frequent large marine transgressions and regressions (Han, 1990; Wu et al., 1995; Wang and Pfefferkorn, 2013; Shao et al., 2015). A complete sedimentary succession (mostly consisting of the Taiyuan Formation; the lower part of the Benxi Formation is very thin or even lacking) that continued to the Permian thus developed (Wu et al., 1995; Sun et al., 2010). The depositional succession in the HCB formed at the Carboniferous-Permian transition was developed in marine-to-terrestrial transitional environments. It consists of 11 to 13 limestone layers with intercalations of mudstone and sandstone intervals, comprising thin coal seams (Fig. 2).

The limestones in the HCB reach a joint thickness of up to $60 \mathrm{~m}$, which is more than elsewhere on the NCB (Fig. 3). The limestones in the HCB are overlain by $>1500$ m of Permian, Mesozoic and Cenozoic sediments.

The fossils in the Taiyuan Formation reflect the position in the continental/marine transition zone; alternation of transgressions and regressions is indicated by vertical changes in the frequency of species with preferred habitats at different depths. Roughly speaking, the transgressions are reflected in the sediments by the presence of fauna, whereas the fossils in sediments accumulated during a regression are richer in (washedin) flora. These interpretations are supported by thin-section analysis of the limestone samples which show various microfacies, which can be related to specific conditions of the depositional environment (Flügel, 2010).

It is considered out of scope here to go into detail with regard to the microfacies, as it is well-known that they tend to change rapidly, both laterally and vertically, in successions deposited in an epeiric sea. Considering the size of the epeiric sea (see Fig. 1B), it is not surprising that the Taiyuan Formation also extends over hundreds of kilometres (Fig. 3), and that a large variety of microfacies is present. We refer the interested reader to the literature that focuses on this aspect (e.g., Li and Wang, 2006), though for other regions.

Fusulinids (Quasifusulina sp., Schwagerina sp., Rugosofuoulina sp., Triricites sp.) are the most abundant fossils, together with corals (Cyathocarinia maoergouensis, Amplexocarinia sp., Neokoninckophyllum tortum, Caninophyllum dobro-lyubovae), conodonts (Streptognathodus elegantulus, Idiognathodus hebeiensis, S. elongates, S. wabaunensis, S. 


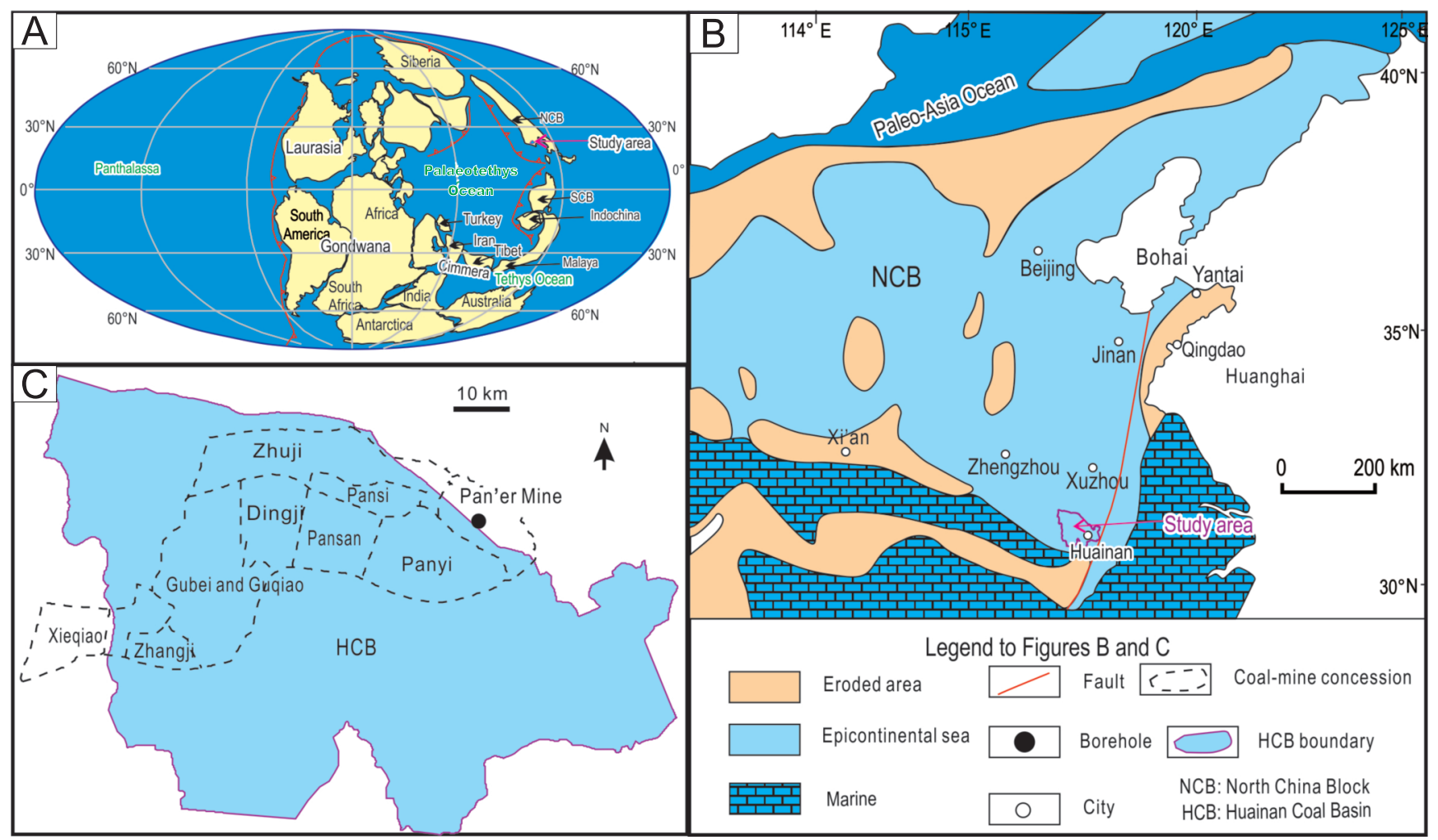

Fig. 1. Location map

A - location of the study area in its plate-tectonic context (after Scotese et al., 2005); B - location of the study area in the North China Block in present-day China (after Wang et al., 1985); C - Huainan Coal Basin with location of the Pan'er Mine where the samples were collected

fuchengensis), crinoids, ammonites and brachiopod fragments (Ge et al., 1985; Gao, 1988; Han, 1990; Fan et al., 1999; Wan et al., 2017; Zhang, 2017). The plant remains (e.g., Neuropteris pseudovata, Annularia cf. orientalis, Lepidodendron posthumii) belong to the typical Cathaysian floral realm of China (Hilton et al., 2001; Wang, 2010; Wang et al., 2012).

In spite of the numerous fossils, the exact depositional environment of the Taiyuan Formation is still controversial, and sedimentological structures and other features have not been studied in any detail thus far, so that little is known yet about the depositional setting. The fossils are useful, however, for dating, although also in this respect some controversies exist. The formation was previously considered - mainly on the basis of macrofossils - as Upper Carboniferous (e.g., Han, 1990), but more recently it was suggested - mainly on the basis of microfossils - that the middle and upper parts of the formation are Lower Permian (Asselian), while the lower part would be Upper Carboniferous (Kasimovian to Gzhelian) (Wang, 2010; Wang and Pfefferkorn, 2013).

\section{METHODS}

Particularly for the investigation of samples regarding their geochemistry and isotope anomalies, both the way of sampling and the analytical methods are of prime importance. Both aspects are therefore dealt with in the following sections, but - in order to avoid duplication of information - the reader is also referred to earlier literature about the use of trace elements and of carbon an oxygen isotopes for establishing the depositional en- vironment, particularly as far as a fresh-water or marine setting is concerned (see, for a comparable case study, Yang et al., 2017).

\section{SAMPLING}

The Taiyuan Formation contains limestone layers that all have been sampled and analysed in order to determine the precise continental-to-marine transitional depositional environments of the epicontinental sea in which it was deposited. The samples were collected in the Pan'er Coal Mine, which is located in the northern part of the HCB. The limestone samples were collected when borehole P2 was drilled for coal exploration. The Taiyuan Formation in the drilled core has a length of $105 \mathrm{~m}$, including 13 layers of limestone (Fig. 2); the individual limestone layers are $0.44-3.58 \mathrm{~m}$ thick and they have a cumulative thickness of $\sim 50 \mathrm{~m}$. The limestones were numbered, following the practice during drilling, from top to bottom as L1 to L12; limestone L3 was split up into an upper part (L3u) and a lower part (L3I), because of a fairly abrupt change from few to many fossil fragments and from moderate to abundant calcite infillings.

It was found during drilling of borehole P2 that the Taiyuan Formation is separated in this borehole by a clear unconformity from the underlying Ordovician. A black mudstone layer of $\sim 5 \mathrm{~m}$ thick forms the top part of the Taiyuan Formation (Fig. 2); its nature is still not clear. Considering the composition of the Taiyuan Formation, it might be speculated that it represents a weathering profile, related to exposure that, in turn, might be related to the unconformity. 


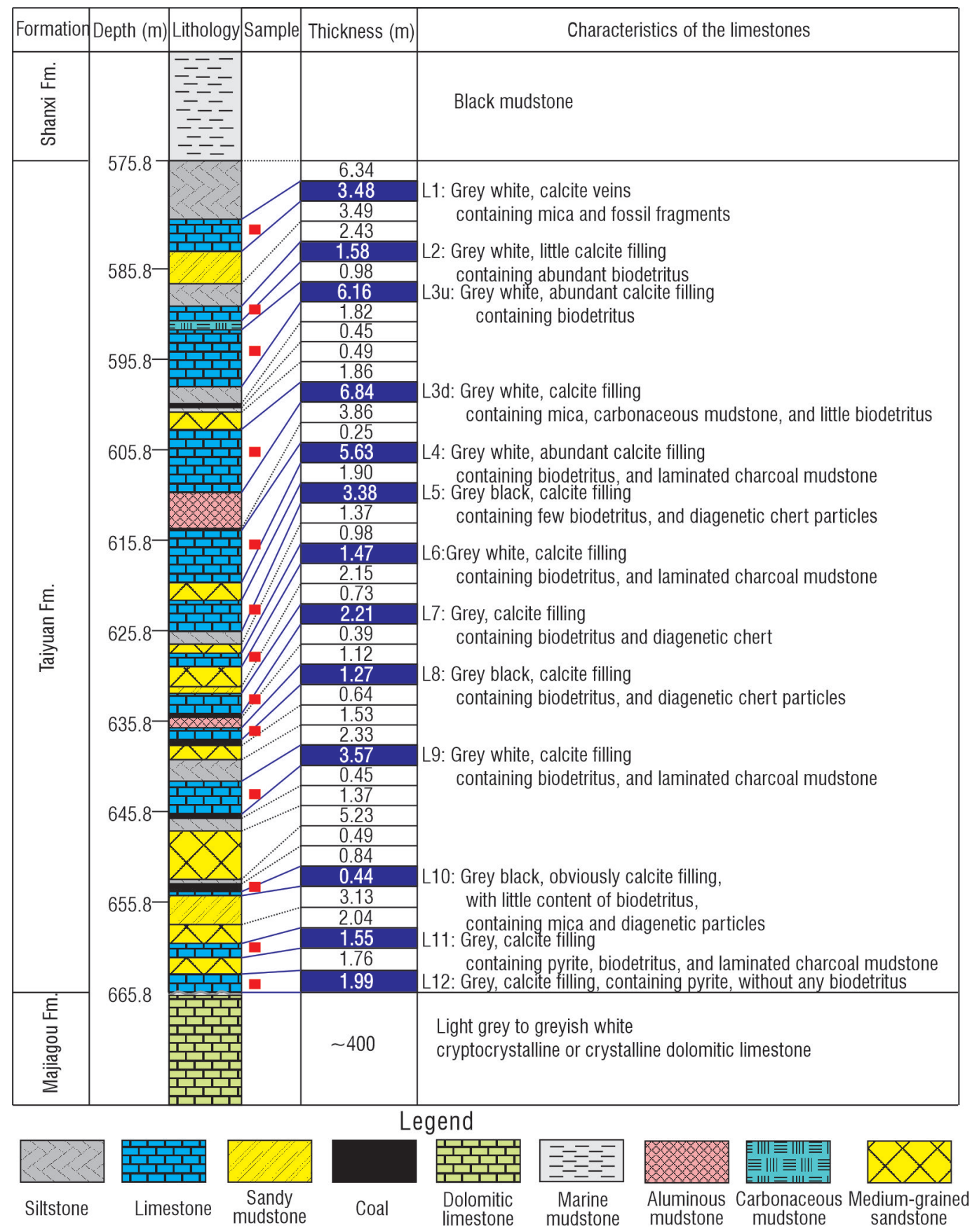

Fig. 2. Schematic succession and characteristics of the Taiyuan Formation as found in coal-exploration borehole P2 in the Huainan Coalfield (modified after Wu and Zhang, 2019)

Most of the limestones of the Taiyuan Formation are pale to grey bioclastic micritic wacke- to packstones composed of abundant invertebrate fossil fragments. Several limestone layers contain admixtures of clay (sometimes carbonaceous clay), with some intraclasts and ooids.

From the 13 limestone levels, 41 samples were collected. Samples with abundant admixtures of terrestrial debris or with obvious post-depositional (diagenetic) features such as recrystallized calcite crystals, calcite veins or framboidal pyrite were excluded from the analyses. This left 13 samples (see Fig. 2) that have been investigated for their trace elements and carbon and oxygen isotopes; they are considered representative for the entire succession.

\section{ANALYTICAL METHODS}

The samples collected from the 13 limestone levels were fragmented into pieces; the outside parts were discarded, and the fragments from the interior were cleaned ultrasonically in purified water. Some representative fragments were polished, and thin sections were prepared from other representative fragments in order to investigate their morphological and structural characteristics by optical microscopy (reflected light) and by light-scattering scanning electron microscopy (SEM, XL30ESEM; Fig. 4). This sedimentology-oriented investigation is, however, not the object of the present study (see the Objectives 


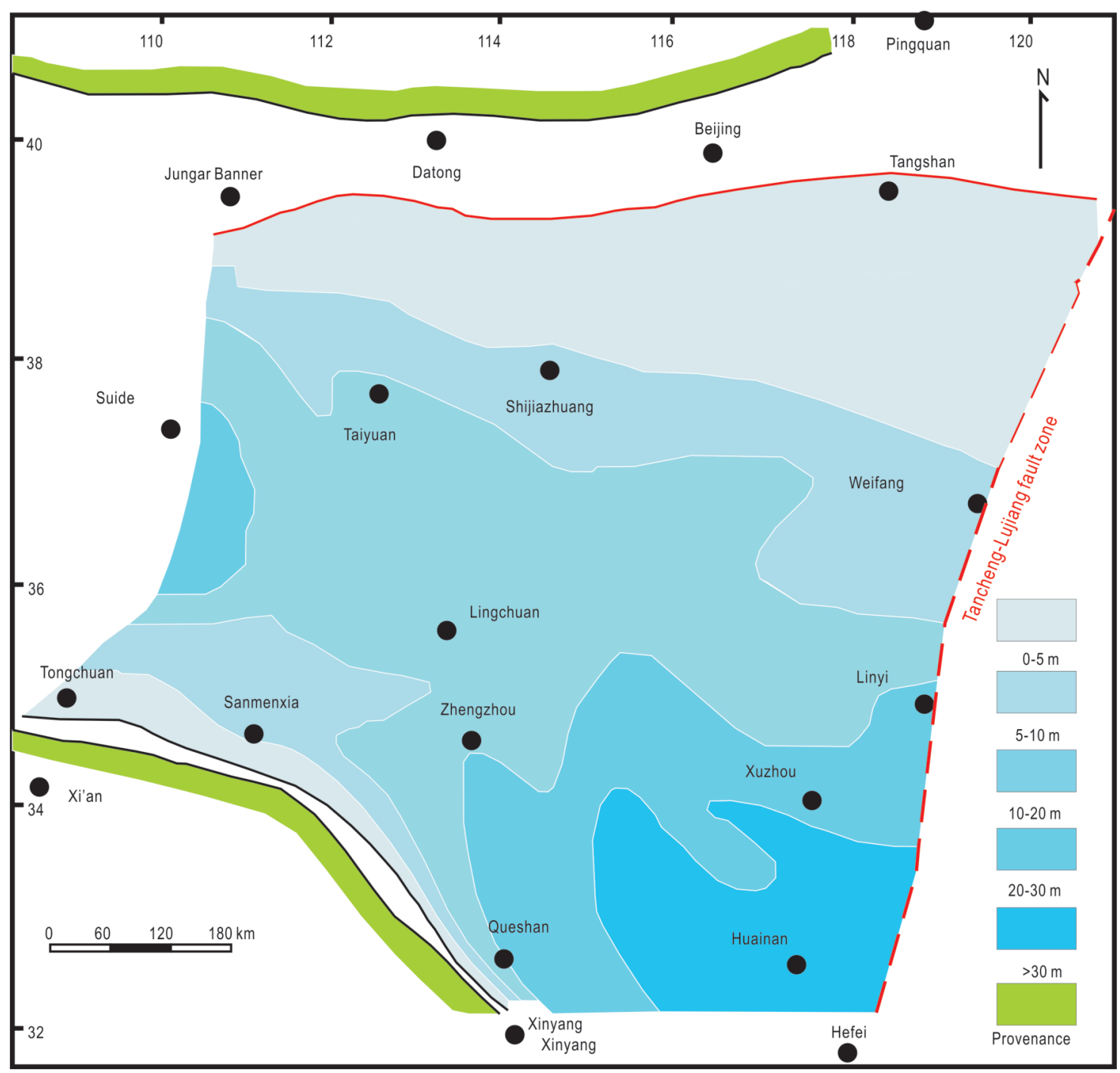

Fig. 3. Total thickness of the limestones in the Taiyuan Formation (modified from Wu et al., 1995)

The source areas represent elevated areas that underwent erosion and supplied clastics to the epeiric sea in which the Taiyuan Formation accumulated

of the study) and is consequently dealt here with only by providing some representative photomicrographs (Fig. 4) which provide a general picture rather than sedimentological details. The chemical analyses were carried out following the GB/T 14506.30-2010 standard (AQUSIC, 2010). The fresh and clean limestone samples were crushed and sieved to obtain particles of $<200 \mu \mathrm{m}$. Approximately $200 \mathrm{mg}$ of the powdered samples were dissolved in a mixture of the acids $\mathrm{HNO}_{3}, \mathrm{HCl}$ and $\mathrm{HF}$ (ratio $3: 1: 1$ ) in a microwave oven.

The resultant solutions were diluted and spiked following the Chinese national standard GB/T14506.30-2010 (AQUSIC, 2010) for trace-element analyses by inductively coupled plasma mass spectrometry (ICP-MS, X series II) at the laboratory of the University of Science and Technology of China at Hefei (prov. Anhui). The relative inaccuracies of these measurements are $<5 \%$ for most of the elements, as evaluated by analysis of certified reference material.

The oxides of major elements $\left(\mathrm{SiO}_{2}, \mathrm{Al}_{2} \mathrm{O}_{3}, \mathrm{CaO}, \mathrm{K}_{2} \mathrm{O}\right.$, $\mathrm{Na}_{2} \mathrm{O}, \mathrm{Fe}_{2} \mathrm{O}_{3}, \mathrm{MnO}, \mathrm{MgO}, \mathrm{TiO}_{2}$, and $\mathrm{P}_{2} \mathrm{O}_{5}$ ) were analysed by
X-ray fluorescence spectrometry (XRF) using the method proposed by Kimura (1998). The results are shown in Table 1.

For $\delta^{13} \mathrm{C}$ and $\delta^{18} \mathrm{O}$ measurements, sample powders were mixed with pure phosphoric acid in vacuum at $25^{\circ} \mathrm{C}$. The $\mathrm{CO}_{2}$ that was produced was measured with a Finnigan MAT-252 mass spectrometer. The isotopic results are denoted in the present contribution in the form of delta notation $\left(\delta^{13} \mathrm{C}, \delta^{18} \mathrm{O}-\right.$ in $\%$ ), relative to the Vienna Pee Dee Belemnite (VPDB) standard (Coplen et al., 1983), which has a value of 0.011180 . The uncertainties of both $\delta^{13} \mathrm{C}$ and $\delta^{18} \mathrm{O}$ are $<0.1 \%$.

\section{RESULTS}

As indicated above, the main analytical methods were concentration measurements of some trace and major elements, and determination of the carbon and oxygen isotopes. The results of these analyses are presented in the following sections. 

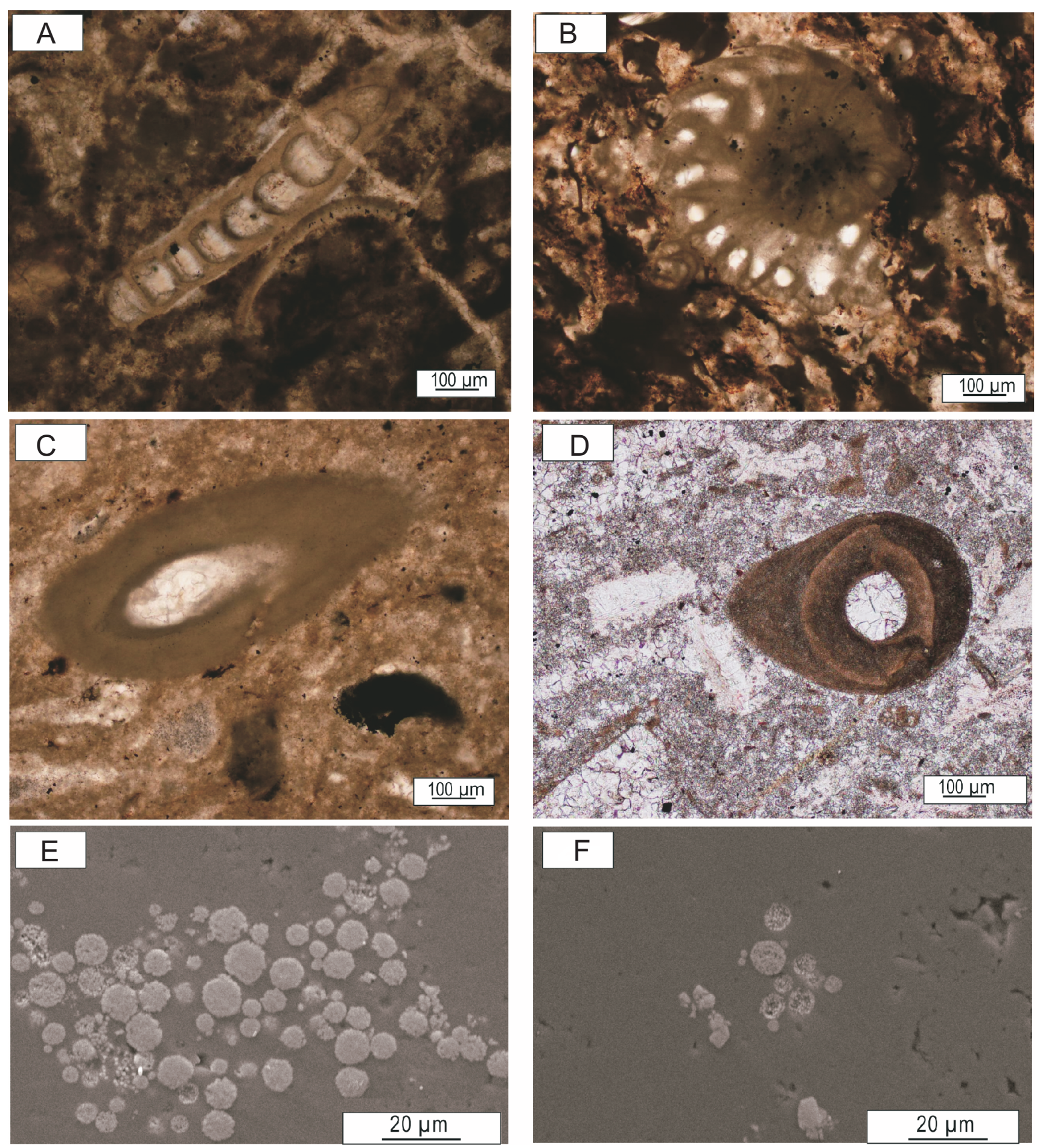

Fig. 4. Microphotographs of the Taiyuan Formation limestones

A - unidentifiable foraminifers (optical microscope, reflected light), sample L5 (= from limestone layer L5); B - unidentifiable foraminifers (probably fusulinids) (optical microscopy, reflected light), sample L8; C - recrystallized calcite (optical microscope, reflected light), sample L7; note the microfossils in the centre; D - recrystallized calcite (optical microscope, reflected light), sample L12; note the microfossils in the centre; E - framboidal pyrite inclusions (SEM, backscatter light), sample L6; F - framboidal pyrite inclusions (SEM, backscatter light), sample L9

\section{MAJOR AND TRACE ELEMENTS}

The most common oxide is $\mathrm{CaCO}_{3}$ (52-95\%); the other oxides are commonly $<5 \%$, except for $\mathrm{MgO}$ in several layers ( $\mathrm{Ta}-$ ble 2). The XRD spectra indicate that calcite is the major mineral, accompanied by relatively large amounts of quartz in the sample from limestone $\mathrm{L} 7\left(7.2 \% \mathrm{SiO}_{2}\right)$ and dolomite in $\mathrm{L} 12$ (20\% MgO).

The variations of redox-sensitive elements such as $\mathrm{Cd}, \mathrm{Cr}$, Mo, and $\mathrm{V}$ in the limestones are positively coupled with each other, but show a negative correlation with $\delta^{13} \mathrm{C}$ (Fig. 5). Except for $\mathrm{Sc}(0.41 \pm 0.11 \mu \mathrm{g} / \mathrm{g}, 1 \sigma)$, the other elements that are not sol- 
Table 1

Geochemical compositions [in wt.\%] of the limestone samples collected from the Taiyuan Formation

\begin{tabular}{|l|r|c|c|c|c|c|c|c|c|}
\hline Sample & $\mathrm{MgO}$ & $\mathrm{CaO}$ & $\mathrm{SiO}_{2}$ & $\mathrm{P}_{2} \mathrm{O}_{5}$ & $\mathrm{FeO}$ & $\mathrm{Al}_{2} \mathrm{O}_{3}$ & $\mathrm{Na}_{2} \mathrm{O}$ & $\mathrm{CO}_{2}$ & Total \\
\hline $\mathrm{L} 1$ & 1.3 & 50.4 & 0.1 & 0.1 & 1.1 & 0.4 & 0.2 & 46.4 & 100 \\
\hline $\mathrm{L} 2$ & 10.5 & 36.3 & 0.1 & 0.2 & 7.2 & 1.1 & 0.1 & 44.5 & 100 \\
\hline $\mathrm{L} 3 \mathrm{u}$ & 2.1 & 49.7 & 0.2 & 0.1 & 1.4 & 0.8 & 0.3 & 45.4 & 100 \\
\hline $\mathrm{L} 3 \mathrm{~d}$ & 10.6 & 35.1 & 0.1 & 0.2 & 5.6 & 1.4 & 0.1 & 46.9 & 100 \\
\hline $\mathrm{L} 4$ & 1.6 & 50.8 & 0.3 & 0.3 & 1.2 & 0.6 & 0.6 & 44.6 & 100 \\
\hline $\mathrm{L} 5$ & 0.8 & 53.1 & 0.1 & 0.1 & 0.5 & 0.5 & 0.1 & 44.8 & 100 \\
\hline $\mathrm{L} 6$ & 9.4 & 37.4 & 0.4 & 0.2 & 6.4 & 1.9 & 0.1 & 44.2 & 100 \\
\hline $\mathrm{L} 7$ & 1.8 & 47.2 & 7.2 & 0.2 & 1.6 & 1.2 & 0.5 & 40.3 & 100 \\
\hline $\mathrm{L} 8$ & 2.3 & 49.6 & 0.4 & 0.3 & 1.2 & 0.7 & 0.4 & 45.1 & 100 \\
\hline $\mathrm{L} 9$ & 1.8 & 49.8 & 0.3 & 0.1 & 1.7 & 1.1 & 0.3 & 44.9 & 100 \\
\hline $\mathrm{L} 10$ & 2.6 & 49.4 & 0.2 & 0.4 & 1.3 & 0.8 & 0.1 & 45.2 & 100 \\
\hline $\mathrm{L} 11$ & 1.8 & 51.1 & 0.1 & 0.2 & 1.2 & 0.9 & 0.3 & 44.4 & 100 \\
\hline $\mathrm{L} 12$ & 20.2 & 29.1 & 0.4 & 0.4 & 4.6 & 1.5 & 0.1 & 43.7 & 100 \\
\hline
\end{tabular}

Table 2

Trace-elements $(\mu \mathrm{g} / \mathrm{g})$ data and anomalies of the carbon and oxygen isotopes in the limestone samples from the Taiyuan Formation

\begin{tabular}{|c|c|c|c|c|c|c|c|c|c|c|c|c|c|c|c|c|c|c|c|}
\hline $\begin{array}{l}\text { Sam- } \\
\text { ple }\end{array}$ & $\mathrm{Ba}$ & $\mathrm{Cd}$ & Co & $\mathrm{Cr}$ & $\mathrm{Mn}$ & Mo & $\mathrm{Ni}$ & Sc & $\mathrm{Sr}$ & V & U & Th & $\begin{array}{l}\mathrm{Mn} / \\
\mathrm{Sr}\end{array}$ & $\stackrel{\mathrm{Th} /}{\mathrm{U}}$ & $\mathrm{V} / \mathrm{Cr}$ & $\mathrm{Sr} / \mathrm{Ba}$ & $\begin{array}{l}\delta^{13} \mathrm{C} \\
{[\% \circ]}\end{array}$ & $\begin{array}{l}\delta^{18} \mathrm{O} \\
{[\% \circ]}\end{array}$ & Z \\
\hline L1 & 68.13 & 0.07 & 0.48 & 26.64 & 390.02 & 0.13 & 3.63 & 0.49 & 751.89 & 13.43 & 1.12 & 2.91 & 0.52 & 2.59 & 0.50 & 11.04 & 0.81 & -10.43 & 123.8 \\
\hline $\mathrm{L} 2$ & 124.84 & 0.76 & 1.15 & 62.86 & 340.05 & 2.73 & 25.31 & 1.61 & 788.72 & 34.90 & 1.01 & 2.34 & 0.43 & 2.32 & 0.56 & 6.32 & -0.81 & -10.33 & 120.5 \\
\hline L3u & 26.81 & 0.14 & 0.21 & 25.09 & 278.03 & 0.21 & 3.45 & 0.12 & 537.96 & 8.93 & 0.85 & 2.11 & 0.52 & 2.48 & 0.36 & 20.06 & 0.35 & -10.30 & 122.9 \\
\hline L3d & 21.41 & 0.08 & 0.21 & 17.86 & 283.70 & 0.14 & 2.27 & 0.34 & 366.19 & 5.71 & 0.87 & 2.14 & 0.77 & 2.45 & 0.32 & 17.11 & 2.98 & -11.13 & 127.9 \\
\hline L4 & 18.32 & 0.09 & 0.15 & 14.36 & 246.25 & 0.24 & 2.14 & 0.22 & 367.37 & 4.33 & 0.31 & 2.47 & 0.67 & 7.93 & 0.30 & 20.05 & 2.30 & -11.60 & 126.2 \\
\hline L5 & 12.65 & 0.16 & 0.08 & 11.29 & 337.56 & 0.27 & 2.42 & 0.05 & 585.34 & 3.38 & 0.73 & 3.02 & 0.58 & 4.14 & 0.30 & 46.29 & 1.48 & -11.87 & 124.4 \\
\hline L6 & 79.98 & 0.23 & 0.59 & 16.54 & 190.62 & 0.52 & 6.59 & 0.23 & 495.24 & 7.45 & 0.54 & 1.82 & 0.38 & 3.37 & 0.45 & 6.19 & 0.27 & -8.89 & 123.4 \\
\hline L7 & 36.05 & 0.53 & 0.19 & 44.84 & 197.46 & 1.22 & 2.99 & 0.15 & 600.14 & 13.40 & \begin{tabular}{|l|}
0.71 \\
\end{tabular} & 2.42 & 0.33 & 3.41 & 0.30 & 16.65 & -1.06 & -10.30 & 119.8 \\
\hline L8 & 23.66 & 0.14 & 0.28 & 21.30 & 742.85 & 0.71 & 5.08 & 0.57 & 397.98 & 5.85 & 1.24 & 2.85 & 1.87 & 2.30 & 0.27 & 16.82 & 0.75 & -10.07 & 123.8 \\
\hline L9 & 18.36 & 0.21 & 0.24 & 18.60 & 253.66 & 0.36 & 4.37 & 0.37 & 246.97 & 7.13 & 1.08 & 4.23 & 1.03 & 3.92 & 0.38 & 13.45 & 0.58 & -9.30 & 123.9 \\
\hline L10 & 5.70 & 0.18 & 0.09 & 13.89 & 93.31 & 0.68 & 2.16 & 0.14 & 248.76 & 4.11 & 1.31 & 3.19 & 0.38 & 2.43 & 0.30 & 43.67 & 1.08 & -8.00 & 125.5 \\
\hline L11 & 13.85 & 0.14 & 0.48 & 18.12 & 87.35 & 0.81 & 6.29 & 0.72 & 212.87 & 8.81 & 1.64 & 3.31 & 0.41 & 2.02 & 0.49 & 15.37 & 0.84 & -6.80 & 125.6 \\
\hline L12 & 8.73 & 0.67 & 0.91 & \begin{tabular}{|l|l}
127.44 \\
\end{tabular} & 188.57 & 1.63 & 7.46 & 0.80 & 54.29 & 52.92 & 1.26 & 4.05 & 3.47 & 3.22 & 0.42 & 6.22 & -1.52 & -4.97 & 121.7 \\
\hline
\end{tabular}

uble in sea water, such as $\mathrm{Al}(0.5 \pm 0.06 \%, 1 \sigma)$, Th (1.05 $\pm 0.04 \mu \mathrm{g} / \mathrm{g}, 1 \sigma)$, and $\mathrm{Zr}(2.07 \pm 0.24 \mu \mathrm{g} / \mathrm{g}, 1 \sigma)$, have higher concentrations than in present-day carbonates.

\section{CARBON AND OXYGEN ISOTOPES}

The studied section of cores from the Huainan Coal Basin shows that $\delta^{13} \mathrm{C}$ values vary between -1.52 to $+2.98 \%$, thus covering a range of $4.5 \%$. The range of $\delta^{18} \mathrm{O}$ values is from -11.87 to $-4.97 \%$, thus covering a range of $6.9 \%$ (Table 1 ). Significant negative excursions in $\delta^{13} \mathrm{C}$ values $(-1.5 \%$ for sample $L 12,-1.1 \%$ of $L 7$ and $-0.8 \%$ ofor $L 2$ ) have been found for several limestone layers, with decreasing anomalies from bottom to top. Uncommonly high positive excursions have been found only in layers $L 4$ to $L 3 d(2.3-2.98 \%)$. The $\delta^{13} \mathrm{C}$ values in the remaining layers vary only slightly $(0.27-1.48 \%$ ).
In contrast to $\delta^{13} \mathrm{C}$, the $\delta^{18} \mathrm{O}$ values show a decreasing trend from layer L12 $(-4.97 \%$ ) to L7 $(-10.30 \%$ ), then slightly drops to $-8.89 \%$ in layer L6, before finally stabilizing within a narrow range $(-11.87$ to $-10.30 \%$ for layers $L 5$ to $L 1)$.

\section{ANALYSIS OF THE RESULTS}

If the conditions of the depositional environment are to be reconstructed on the basis of properties of the sediment, it is a prerequisite that changes of these properties due to diagenesis are eliminated first. Although the studied low-Mg calcite (Mg $<6.4 \mu \mathrm{g} / \mathrm{g}$, except in L12) is resistant to alteration during and after deposition (Jacobsen and Kaufman, 1999), we checked whether the samples showed evidence of diagenetic alteration by optical microscopy and SEM; we did so also on the basis of 


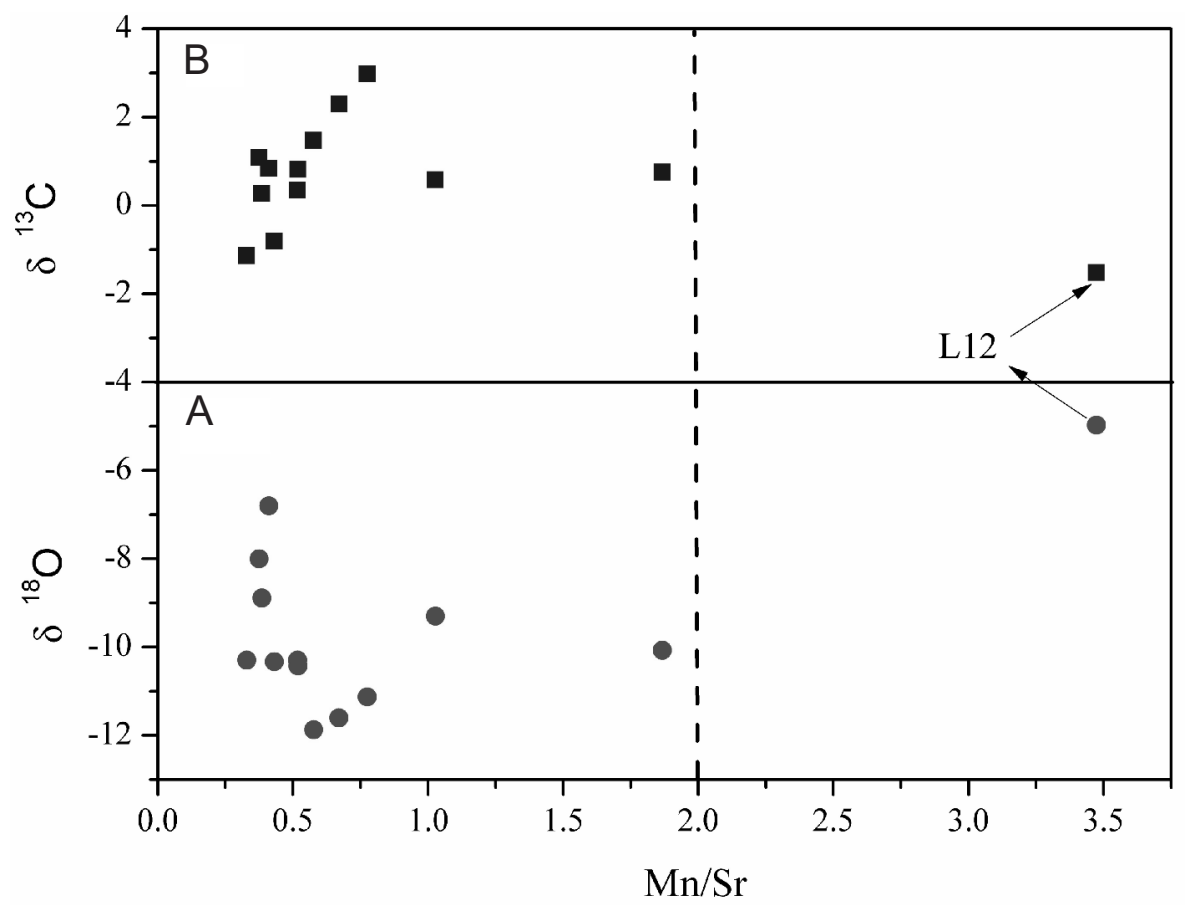

Fig. 5. Correlation of $\delta^{13} \mathrm{C}$ (in \%o) versus $\mathrm{Mn} / \mathrm{Sr}$ ratio (squares) and $\delta^{18} \mathrm{O}$ (in \%o) versus $\mathrm{Mn} / \mathrm{Sr}$ ratio (dots)

Note that sample L12 was probably altered by diagenetic processes

previously established geochemical criteria (Frimmel, 2009), particularly the $\mathrm{Mn} / \mathrm{Sr}$ ratio. Also the $\delta^{13} \mathrm{C}$ and $\delta^{18} \mathrm{O}$ values were measured and analysed. These aspects will therefore be discussed in the following sections.

\section{DIAGENETIC CHANGES OF THE LIMESTONES}

The examination of thin-sections of all 13 limestone levels verified by SEM scanning confirmed that most samples contain clean calcite prisms with smooth boundaries, despite minor alterations in several specimens (Fig. 6); it must thus be deduced that the diagenetic alternations of the limestones were minimal. The original sedimentary lamination found by Han (1990) appeared to be well-preserved, which also indicates that alteration or recrystallization was minimal or even absent.

\section{$\mathrm{Mn} / \mathrm{Sr}$ RATIO}

The $\mathrm{Mn} / \mathrm{Sr}$ ratio is a commonly used proxy because it reflects diagenetic processes. Strontium is sensitive to meteoric diagenesis and is easily expelled from marine carbonate (Veizer, 2013). After sedimentation, carbonate rocks will suffer $\mathrm{Sr}$ and $\mathrm{Na}$ losses, while becoming enriched in $\mathrm{Fe}$ and $\mathrm{Mn}$, particularly under the influence of percolating atmospheric water (Frimmel, 2009). The $\mathrm{Mn} / \mathrm{Sr}$ ratio is, consequently, a sensitive indicator to judge the diagenesis and alteration degree of marine carbonate rocks. An $\mathrm{Mn} / \mathrm{Sr}$ ratio of $<10$ is commonly considered (e.g., Gao, 1988; Neuhuber et al., 2007; Ganai et al., 2018) as evidence that the carbonate rocks have not been strongly altered, and that their isotopic composition still records the original sedimentary composition. An $\mathrm{Mn} / \mathrm{Sr}$ ratio of $<2-3$ even indicates that a sample has well maintained the isotopic composition of the original sea water (Grossman et al., 2002).

The $\mathrm{Mn} / \mathrm{Sr}$ ratios measured for our samples are all $<2$, except for the lowest limestone layer (L12), for which $\mathrm{Mn} / \mathrm{Sr}=$ 3.47. This exceptionally high value is due to an extremely low $\mathrm{Sr}$ content (54 versus $213-789 \mu \mathrm{g} / \mathrm{g}$ in the other limestone samples, Table 1). This suggests diagenetic alteration of the L12 limestone. This exceptional character of sample $\mathrm{L} 12$ is supported by the $\mathrm{Mg}(12.1 \%)$, Th $(4.05 \mu \mathrm{g} / \mathrm{g}), \mathrm{Al}(0.79 \%)$ and $\delta^{18} \mathrm{O}$ $(-4.97 \%$ ) values of this sample, which are significantly higher than in the other limestone samples (Table 1).

It must consequently be deduced that the $\mathrm{Mn} / \mathrm{Sr}$ ratios of the limestones indicate that the composition of the original sea water is still reflected by all limestone samples, except L12 (Fig. 5). Apart from the latter sample, diagenetic alteration thus did not play a role of any importance.

\section{CORRELATION BETWEEN $\delta^{18} \mathrm{O}$ AND $\delta^{13} \mathrm{C}$}

The primary $\delta^{18} \mathrm{O}$ and $\delta^{13} \mathrm{C}$ values of carbonates inherited from sea water usually decrease after burial as a result of the percolation of meteoric water and/or hydrothermal fluids, and thus can indicate the degree of diagenesis. A positive correlation between $\delta^{13} \mathrm{C}$ and $\delta^{18} \mathrm{O}$ makes alteration of carbonates likely. The limestone samples under study show a correlation between $\delta^{13} \mathrm{C}$ and $\delta^{18} \mathrm{O}$, indeed $(r=0.52$, Fig. 6), although they have lower $\delta^{18} \mathrm{O}$ values $(-11.9$ to $-5.0 \%$ ) than representative Carboniferous marine carbonates elsewhere in the world, which are -3\%o (Brand, 1982; Algeo and Maynard, 2004; Kuleshov et al., 2018), and also lower than Carboniferous marine limestones present on the South China Block, which have values in the range of -6.5 to $-4.5 \%$ (Zhao and Zheng, 2014). 


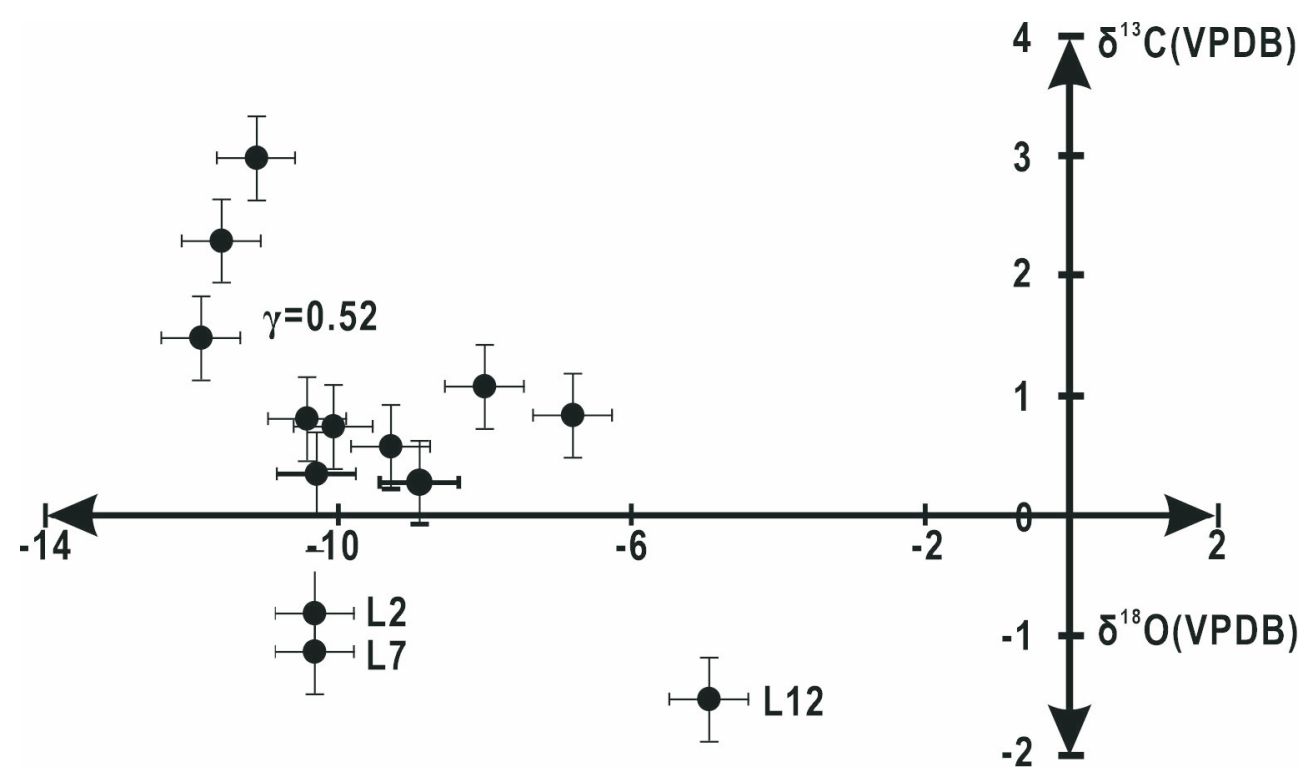

Fig. 6. Correlation between the $\delta^{13} \mathrm{C}$ (vertical axis, in \%o) and $\delta^{18} \mathrm{O}$ values (horizontal axis, in \%o) of the limestones in the Taiyuan Formation

The limestones L2, L7 and L12, which have anomalous values, are individually indicated

It can thus be deduced that the $\delta^{18} \mathrm{O}$ and $\delta^{13} \mathrm{C}$ values of the Taiyuan limestone samples do not show a clear positive correlation, indicating that the limestones preserved the carbon- and oxygen-isotope compositions of the sea water in which they accumulated.

\section{IMPLICATIONS OF THE $\delta^{18}$ O VALUES}

The oxygen-isotope composition of carbonate rocks is sensitive to alteration. The initial $\delta^{18} \mathrm{O}$ value of calcareous sediments will, however, be distinctly reduced during diagenesis because of interaction between the sediment and percolating water. Quantitative research is, however, inconclusive. A value of $\delta^{18} \mathrm{O}<-5.0 \%$ in carbonate rock indicates, as a rule, that the carbonates were affected by alteration; of $\delta^{18} \mathrm{O}<-10.0 \%$, the carbonates have undergone strong alteration, and the oxygenand carbon-isotope data of the sample can consequently not be used (Han, 1990).

Kaufman et al. (1993) came to the conclusion that $\delta^{18} \mathrm{O}$ $<-11.0 \%$ should be taken as the boundary value. Consequently, the limestone samples L3d, L4 and L5 would, following these authors, have undergone diagenetic alteration. This would imply that the carbon- and oxygen-isotope data of these three samples are no reliable indicators for the sedimentary environment.

Because samples L3d, L4, L5, and L12 may well have been altered by diagenesis, they are not included in the other considerations that lead to the conclusions of the present study.

\section{$\delta^{18} \mathrm{O}$ AND $\delta^{13} \mathrm{C}$ CHEMOSTRATIGRAPHY}

The limestones of the Taiyuan Formation were deposited in an epicontinental sea, and they should record geochemical information reflecting the nature of the terrigenous input and the composition of the sea water. Compared to contemporary carbonate samples from other regions, for instance in the form of brachiopod shells from the Palaeotethys Ocean and Panthalassa (Bruckschen et al., 1999; Mii et al., 2001) and limestones from the South China Block (Zhao and Zheng, 2014), the $\delta^{18} \mathrm{O}$ values of the limestone samples under study here $(-11.87$ to $-4.97 \%$ ) are lower. This might be ascribed to differences in their palaeogeographical zonation, depositional conditions, and the calcareous species that were analysed.

The oxygen-isotope composition in marine carbonates is controlled by several interrelated factors such as glacial/interglacial cycles, fluctuations of the sea level, and the sea water temperature (Ross and Ross, 1988). The decrease in $\delta^{18} \mathrm{O}$ from bottom to top in the succession of the Taiyuan limestone layers indicates a contemporarily lowered sea water $\delta^{18} \mathrm{O}$, probably caused by gradual climate warming and the consequent sea level rise.

The $\delta^{13} \mathrm{C}$ of an ocean system is influenced by the presence of organic matter, dissolved carbonic acids, nutrient supply, $\mathrm{pCO}_{2}$, buried organic carbon, and sea level fluctuations (McConnaughey, 1989; McConnaughey et al., 1997). The burial of organic carbon and stronger photosynthesis will commonly cause an increase of the $\delta^{13} \mathrm{C}$ in both sea water and carbonate sediments. The $\delta^{13} \mathrm{C}$ in the limestone under study shows three negative anomalies in the lower (L2), middle (L7) and upper (L12) parts of the succession; the values for these three layers are $-1.1,-0.8$ and $-1.5 \%$, respectively. These negative excursions in $\delta^{13} \mathrm{C}$ are possibly related to short-lived enhanced terrigenous weathering in a warm climate.

The three just-mentioned limestone layers (L2, L7 and L12) also have the highest concentrations of redox-sensitive elements, viz. Cd, Cr, Mo and V. These elements tend to be enriched in sediments that accumulated in an oxygen-depleted environment. It is consequently reasonable to assume that these three limestone layers were deposited in an epicontinental ocean with a relatively high sea level. Thin-sections from these three limestone layers shows less fossil fragments than the thin-sections from other layers. This low amount of biogenic fragments in the limestones also suggests worsening conditions for the biotope that was previously used to clear water and a low sediment supply, but that now became confronted with an enhanced terrigenous input. 
In contrast, the samples from layers $L 3 d$ and $L 4$ show positive anomalies of $\delta^{13} \mathrm{C}$, with peak values of 3.0 and $2.3 \%$, respectively. These two limestone layers contain more shell fragments than the other layers, suggesting less terrigenous input and thus enhanced organic carbon burial. It is important in this context that $\delta^{13} \mathrm{C}$ in limestone is more sensitive to climate changes than $\delta^{18} \mathrm{O}$.

\section{INTERPRETATION OF THE DEPOSITIONAL ENVIRONMENT}

Carbon- and oxygen-isotope compositions provide indications about the salinity of the aqueous depositional environment. The redox conditions of the environment influence the solubility of redox-sensitive elements in the sea water, and can enrich or impoverish these elements in the sediment. Hence, concentrations or ratios of specific redox-sensitive trace elements are commonly used to reconstruct the redox conditions in ancient sedimentary systems (e.g., Dean et al., 1999; Yarincik et al., 2000; Morford et al., 2001; Pailler et al., 2002).

Several of these proxies are therefore presented and discussed below in order to reconstruct the environment in which the Taiyuan Formation was deposited.

\section{SALINITY OF THE DEPOSITIONAL ENVIRONMENT}

Two proxies are commonly used to interpret the salinity if an ancient aqueous depositional environment. These concern the $\delta^{13} \mathrm{C}$ and $\delta^{18} \mathrm{O}$ values, and the $\mathrm{Sr} / \mathrm{Ba}$ ratio.

$$
\begin{gathered}
\text { SALINITY AS DEDUCED } \\
\text { FROM THE } \delta^{13} \mathrm{C} \text { AND } \delta^{18} \mathrm{O} \text { VALUES }
\end{gathered}
$$

The benchmark study by Keith and Weber (1964) proposed correctly, as confirmed in later studies (see also Latal et al., 2004; Guo et al., 2019), an empirical equation for estimating the salinity of aqueous depositional environments by using $\delta^{18} \mathrm{O}$ (with respect to SMOW - Standard Mean Ocean Water, in \%o) and $\delta^{13} \mathrm{C}$ (with respect to PDB - Pee Dee Belemnite, in \%):

$$
Z=2.048 \times\left(\delta^{13} C+50\right)+0.498 \times\left(\delta^{18} O+50\right)
$$

where: $Z$ - palaeosalinity.

If $Z>120$, the carbonate was probably deposited in a high-salinity marine environment; if $Z<120$, deposition took place in a low-salinity marine or a non-marine (lacustrine) environment. The $Z$ values have been calculated for all Taiyuan limestone layers and were found to vary from 119.8 to 128.0 , suggesting that they were predominantly deposited in a highsalinity marine environment. The L7 limestone layer, which contains abundant quartz particles, has the lowest $Z$ value (119.8), suggesting that it was possibly deposited in a transitional (continental-to-marine) environment (Fig. 6).

\section{SALINITY AS DEDUCED FROM THE Sr/Ba RATIO}

$\mathrm{Sr}$ and $\mathrm{Ba}$ represent a unique group of coherent elements with similar geochemical properties. Their distributions vary closely with salinity, and are more easily concentrated in sea water than fresh water (Schmitz et al., 1997). Several sedimentary environments can affect the Sr/Ba ratio, due to the differences in chemical behaviour of these two elements.

The solubility of $\mathrm{Ba}$ compounds is distinctly lower than that of $\mathrm{Sr}$ compounds, so that $\mathrm{Ba}$ commonly precipitates as $\mathrm{BaSO}_{4}$ if sulphate is present in the water (Van Os et al., 1991). The Sr/Ba ratio can consequently be used as an indicator to estimate the marine or continental (mostly lacustrine) nature of the depositional environment (Van Beek et al., 2003).

An $\mathrm{Sr} / \mathrm{Ba}$ ratio of 1 is considered as the boundary between fresh $(\mathrm{Sr} / \mathrm{Ba}<1)$ and marine $(\mathrm{Sr} / \mathrm{Ba}>1)$. The $\mathrm{Sr} / \mathrm{Ba}$ ratio throughout the limestone succession remains within the range between 6.2 and 46.2 , which is clear evidence of a marine depositional environment.

\section{REDOX CONDITIONS AS DEDUCED FROM GEOCHEMICAL PROXIES}

The concentrations of several chemical elements are, as well as the ratios between some elements, proxies for the redox conditions during (and directly after) sedimentation, as discussed above. The most informative proxies are the combination of $\mathrm{Cd}$ and Mo concentrations, the $\mathrm{V} / \mathrm{Cr}$ ratio, and the $\mathrm{Th} / \mathrm{U}$ ratio.

\section{REDOX CONDITIONS AS DEDUCED FROM}

THE Cd AND MO CONCENTRATIONS

Cd and Mo are both redox-sensitive trace metals, and their solubility under oxidizing conditions is higher than under reducing conditions, consequently resulting in their relative enrichment in oxygen-depleted sedimentary facies (Rosenthal et al., 1997; Adelson et al., 2001). It is commonly agreed upon that carbonates are deposited in an oxygen-depleted environment if the contents of $\mathrm{Cd}$ and Mo are higher than $1 \mu \mathrm{g} / \mathrm{g}$ and $8 \mu \mathrm{g} / \mathrm{g}$, respectively (e.g., Chaillou et al., 2002; Sundby et al., 2004).

In most of our samples, $\mathrm{Cd}$ and Mo are present in concentrations lower than 0.2 and $1.0 \mu \mathrm{g} / \mathrm{g}$, respectively (Fig. 7). This indicates that almost all limestones were deposited in an oxidizing environment.

\section{REDOX CONDITIONS AS DEDUCED FROM THE V/Cr RATIO}

$\mathrm{Cr}$ is commonly present as $\mathrm{CrO}_{4}^{2-}$ in oxidizing environments, and as the reduced form (+3 valence) in reducing environments. $V$ behaves similarly: it is well-soluble in an oxidizing environment $\left(+6\right.$ valence, mainly as $\left.\mathrm{H}_{2} \mathrm{VO}^{4-}\right)$ and less soluble under reducing conditions (Hastings et al., 1996).

Jones and Manning (1994) suggested that $\mathrm{Cr}$ is often incorporated in clastic particles, for example, as a substitute for aluminum in clay minerals, but it can also be absorbed or present as chromite. Vanadium is constrained by organic matter, and is concentrated in reducing environments (Jones and Manning, 1994; Tribovillard et al., 2006). Jones and Manning (1994) detailed that $\mathrm{V} / \mathrm{Cr}<2$ indicates an oxidizing depositional environment, that $2<\mathrm{V} / \mathrm{Cr}<4.25$ indicates somewhat oxidizing conditions, and that $\mathrm{V} / \mathrm{Cr}>4.25$ is evidence of reducing conditions.

The V/Cr ratios of the Taiyuan limestone samples hardly vary, showing distinctly low values, commonly <0.6 (Fig. 7). This indicates pronounced oxidizing conditions of the sea water when the limestones were deposited. 


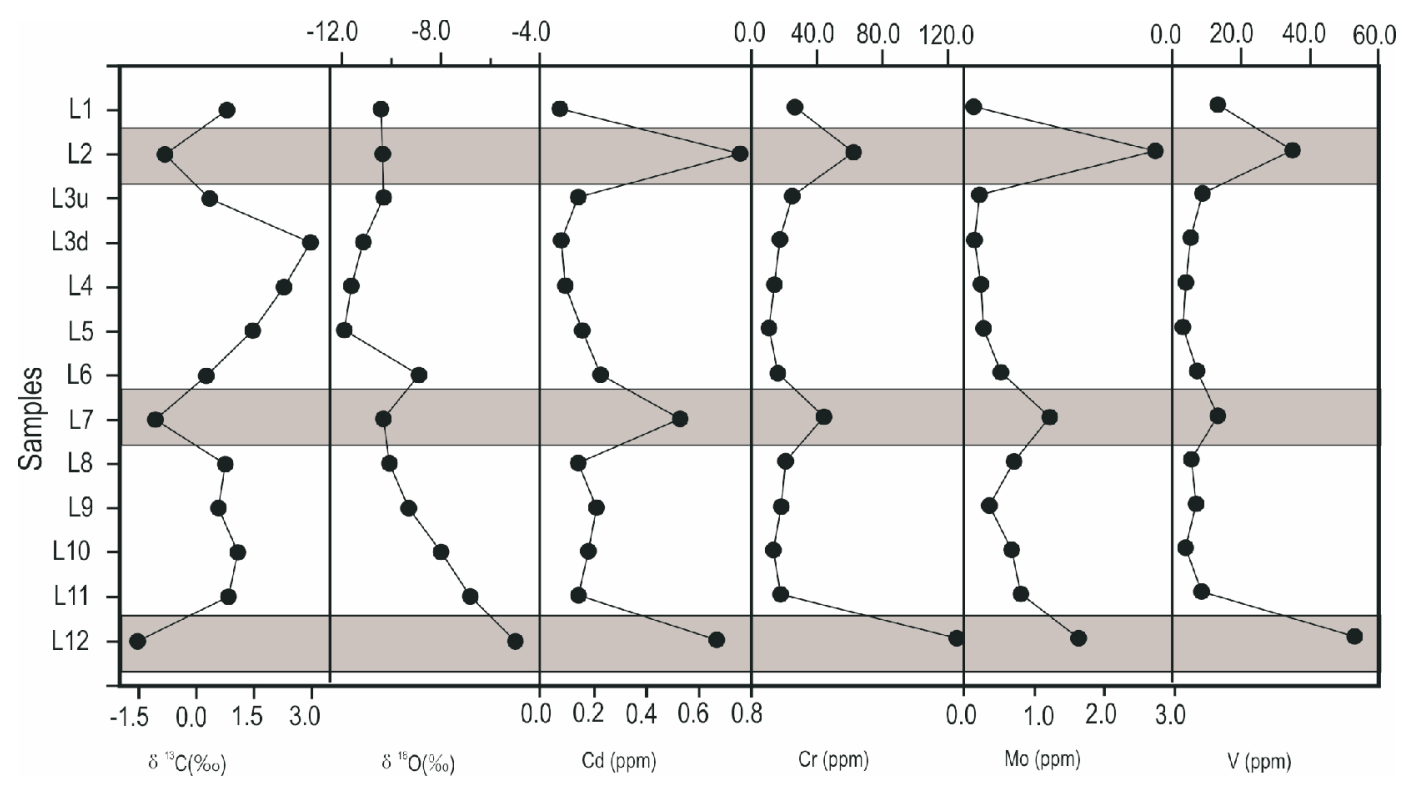

Fig. 7. Vertical variations in the $\delta^{13} \mathrm{C}$ and $\delta^{18} \mathrm{O}$ values (in \%o) and in the $\mathrm{Cd}, \mathrm{Cr}$, Mo and $V$ concentrations in the Taiyuan limestone samples

REDOX CONDITIONS AS DEDUCED FROM THE Th/U RATIO

Uranium ions maintain a high redox state $\left(\mathrm{U}^{+6}\right)$ under oxidizing conditions, forming soluble uranyl carbonates in sea water. Under reducing conditions, however, $\mathrm{U}$ is present in a lower redox state $\left(\mathrm{U}^{+4}\right)$, forming insoluble uranous fluoride, and is trapped into marine carbonates (McManus et al., 2005). Th is less sensitive than $U$ to fluctuations in the redox conditions and remains permanently in its insoluble $\mathrm{Th}^{+4}$ state. This implies that sediments deposited in reducing environments are relatively rich in $U$ and thus have lower $\mathrm{Th} / \mathrm{U}$ values than those in oxidizing environments (Sarin et al., 1990). It was suggested (Pailler et al., 2002) that Th/U $<2,2<T h / U<7$ and Th/U $>7$ in sediments indicate reducing, oxidizing and strongly oxidizing sedimentary environments, respectively.

The Th/U ratios in the Taiyuan limestones vary between 2 and 5 , except for a peak in $L 5(T h / U=7.9)$. This indicates overall oxidizing conditions (Fig. 8).

\section{DISCUSSION}

The Upper Carboniferous to Lower Permian Taiyuan Formation has for a long time raised hot debates about its depositional environment and numerous arguments have been put forward, both in favour and against marine and continental settings (e.g., Han, 1990; Guo and Liu, 2000; Li and Wang, 2006; Song et al., 2011, 2016; Mao et al., 2018; Wang et al., 2019). Part of the controversy is based on different views regarding the fossil content. Terrestrial plant remains have been found, together with species representing a full-marine fauna such as ammonites and crinoids; numerous microfossils have been found as well, many of which indicate a transitional continental-to-marine environment. This might, in principle, be explained by facies shifts in a near-coast environment, but field data do not provide any indication for such facies shifts.
Geochemical and isotope analyses of several chemical elements have therefore been carried out because they have been found in the past decades to be fairly reliable proxies that can help interpret the depositional environment.

The most important analyses carried out for the purpose are the analyses of the $\delta^{13} \mathrm{C}$ and $\delta^{18} \mathrm{O}$ values, and the $\mathrm{Sr} / \mathrm{Ba}$ ratio, because they provide insight into the salinity of the depositional environment. Both proxies indicate a full-marine environment (apart from, possibly, one limestone that may have been deposited in a transitional environment). The common outcome for both proxies supports this finding.

Equally consistent findings were obtained regarding the redox conditions of the depositional environment. The three proxies that were determined ( $\mathrm{Cd}$ and Mo concentrations, the $\mathrm{V} / \mathrm{Cr}$ ratio, and the Th/U ratio) all yield the same outcome: an oxidizing environment. This is consistent with the full-marine setting obtained through the proxies for the salinity.

The consistency between all outcomes must be considered as strong evidence that the findings are correct, even though the accuracies of the various proxies in themselves may be questioned.

Obviously, this unavoidable conclusion raises the question how the terrestrial fossils in the Taiyuan Formation can be explained. There are several possible explanations. One might be that terrestrial plants have been eroded from a coast or, more likely, have been supplied by rivers that discharged in the sea. It is well-known that plants may drift away from their source over long distances in oceans. It seems unlikely, however, that the fairly frequent remains of terrestrial plants in the marine sediments of the Taiyuan Formation have such an origin. A second possibility is that the plants were brought along by sediment gravity flows. Although it has been found that such mass flows can occur even in the mostly fairly shallow environment of epicontinental seas (e.g., Chen et al., 2009; Van Loon et al., 2012; Su et al., 2016; Wang et al., 2020), this seems also unlikely, as no clear indications of mass transport have been described from this formation. 


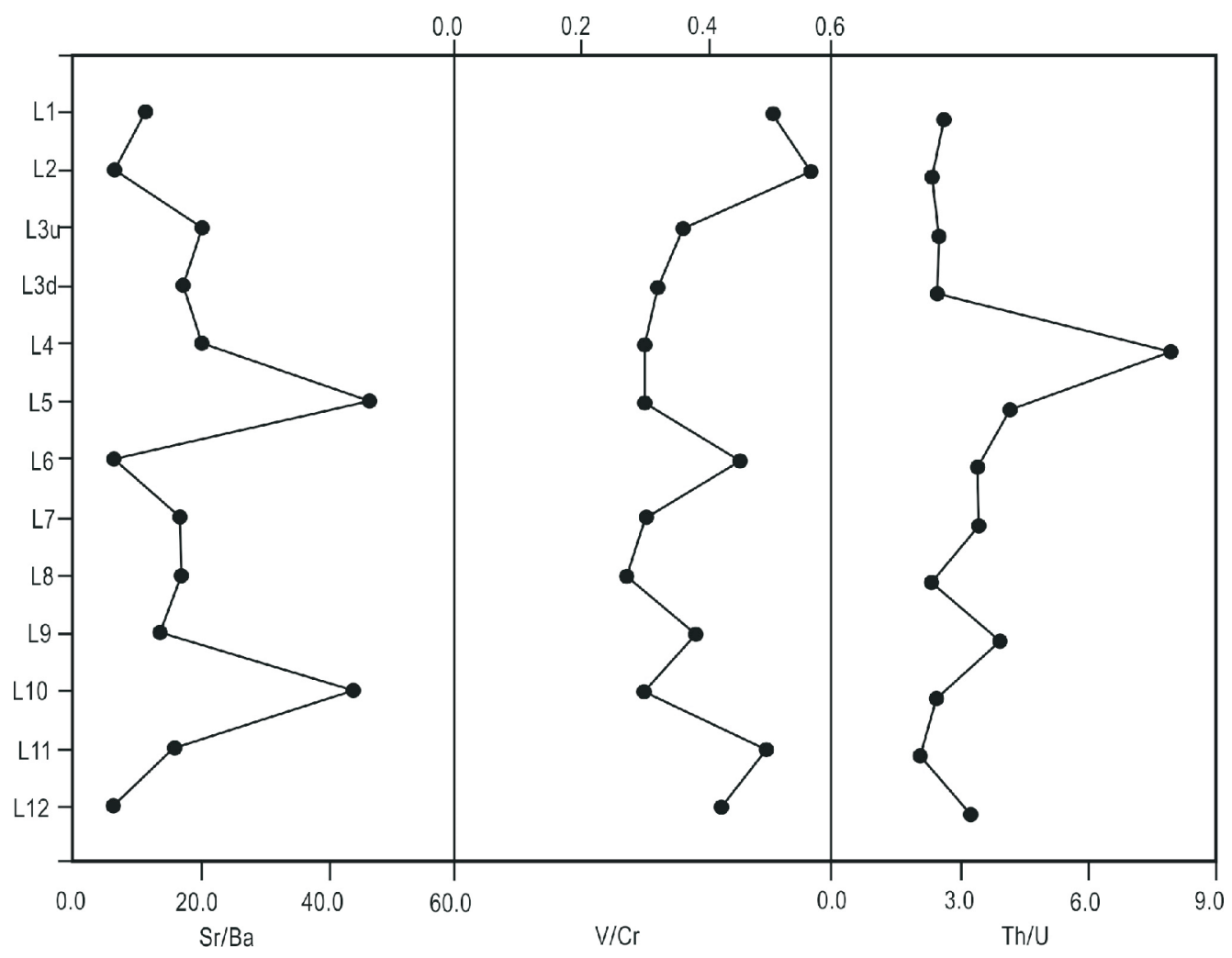

Fig. 8. Distribution of the $\mathrm{Sr} / \mathrm{Ba}, \mathrm{V} / \mathrm{Cr}$ and $\mathrm{Th} / \mathrm{U}$ ratios in the Taiyuan limestone samples

A solution for the "problem" of the terrestrial fossils may be found in the explanation presented for another Chinese formation that was hotly debated for its marine or continental nature for a long time: the Cretaceous Lingshandao Formation on Lingshan Island in the Yellow Sea, $37 \mathrm{~km}$ south of Qingdao. This formation was recently also investigated for its geochemistry (Yang et al., 2017), and it turned out that the geochemical proxies indicate clearly that the setting was marine. Yet there were, like in the Taiyuan Formation, terrestrial (carbonized) plant remains and samples of which the geochemistry indicated brackish, low-salinity conditions.

Analysis of the sedimentary facies of the Lingshandao Formation indicated that not only sediment gravity flows left turbidites and debrites (Yang and Van Loon, 2016; Yang et al., 2016) that brought terrestrial fossils to the deep-marine realm, but that also sudden influxes of fresh water during high-discharge phases of a river lowered the salinity of the ambient sea water temporarily. This anomalous low salinity of the sea water was preserved in the pores of the then deposited hyperpycnites, which are well-recognizable because of their numerous couplets of mm-sized levels of fining-upward and coarsening-upward successions, caused by fluctuations in the discharge of water and/or sediment by the river debouching into the basin. Such high-discharge phases of fresh river water may also explain the apparent low salinity when limestone L7 of the Taiyuan Formation was accumulating. Hyperpycnites and turbidity currents thus can well-explain the temporary relatively low-salinity conditions of the Taiyuan Formation, although the formation was deposited in a full-marine setting.

\section{CONCLUSIONS}

Petrological analyses and geochemical indices $\left(\delta^{13} \mathrm{C}\right.$ versus $\delta^{18} \mathrm{O}$ versus $\mathrm{Sr} / \mathrm{Mn}$ ) of limestone samples from the Taiyuan Formation in the Huainan Coal Basin (North China Block) indicate that almost all limestones have been affected by weak or negligible diagenetic alteration. Three limestone layers are also associated with the high concentrations of redox-sensitive elements (Mo, V, and Cd). These three layers are interpreted to have been deposited in a sea during a high sea level phase thanks to a temporary warmer climate and with more terrigenous input than the other limestone layers. Two layers with positive $\delta^{13} \mathrm{C}$ anomalies suggest less terrigenous input and a higher concentration of organic matter in the sediment. The trace elements and $\delta^{18} \mathrm{O}$ versus $\delta^{13} \mathrm{C}$ indicate a full-marine oxidizing setting. The presence of terrestrial plant fragments and the low-salinity of some limestone samples must be attributed to high-discharge phases of fresh river water that resulted in hyperpycnal flows bringing the terrestrial plant material to the full-marine realm and also temporarily lowering the salinity locally.

Acknowledgements. This study was financially supported by the National Key R\&D Plan of China (Grant No. 2017YFC0601405), the National Natural Science Foundation of China (Grant No. 41772096; 41972170) and the SDUST Research Fund (Grant No. 2018TDJH101). The comments by the journal reviewers M. Krajewski and Anonymous are kindly appreciated. 


\section{REFERENCES}

AQUSIC (General Administration of Quality Supervision, Inspection and Quarantine of the People's Republic of China, Standardization Administration of the People's Republic of China), 2010. GB/T 14506.30-2010. Methods for chemical analysis of silicate rocks - Part 30: Determination of 44 elements. AQSIC, Beijing.

Adelson, J.M., Helz, G.R., Miller, C.V., 2001. Reconstructing the rise of recent coastal anoxia; molybdenum in Chesapeake Bay sediments. Geochimica et Cosmochimica Acta, 65: 237-252.

Algeo, T.J., Maynard, J.B., 2004. Trace-element behavior and redox facies in core shales of Upper Pennsylvanian Kansas-type cyclothems. Chemical Geology, 206: 289-318.

Brand, R., 1982. The oxygen and carbon isotope composition of Carboniferous fossil components: sea-water effects. Sedimentology, 29: 139-147.

Bruckschen, P., Oesmann, S., Veizer, J., 1999. Isotope stratigraphy of the European Carboniferous: proxy signals for ocean chemistry, climate and tectonics. Chemical Geology, 161: 127-163.

Chaillou, G., Anschutz, P., Lavaux, G., Schäfer, J., Blanc, G., 2002. The distribution of $\mathrm{Mo}, \mathrm{U}$, and $\mathrm{Cd}$ in relation to major redox species in muddy sediments of the Bay of Biscay. Marine Chemistry, 80: $41-59$.

Chen, J., Van Loon, A.J., Han, Z., Chough, S.K., 2009. Funnel-shaped, breccia-filled clastic dykes in the Late Cambrian Chaomidian Formation (Shandong Province, China). Sedimentary Geology, 221: 1-6.

Coplen, T.B., Kendall, C., Hopple, J., 1983. Comparison of stable isotope reference samples. Nature, 302: 236-238.

Dean, W.E., Piper, D.Z., Peterson, L.C., 1999. Molybdenum accumulation in Cariaco basin sediment over the past 24 k.y.: a record of water-column anoxia and climate. Geology, 27: 507-510.

Fan, B.H., Zhu, W.B., He, X.L., 1999. Early Permian brachiopod fauna from Yangquan, Shanxi Province. Acta Palaeontologica Sinica, 38: 353-364.

Flügel, E., 2010. Microfacies of Carbonate Rocks - Analysis, Interpretation and Application. Springer-Verlag, Berlin.

Frimmel, H.E., 2009. Trace element distribution in Neoproterozoic carbonates as palaeoenvironmental indicator. Chemical Geology, 258: 338-353.

Ganai, J.A., Rashid, S.A., Romshoo, S.A., 2018. Evaluation of terrigenous input, diagenetic alteration and depositional conditions of Lower Carboniferous carbonates of Tethys Himalaya, India. Solid Earth Sciences, 3: 33-49.

Gao, J., 1988. The Paleoecological features and environmental background of brachiopod from the Taiyuan Formation in Shanxi Province (in Chinese with English summary). Geoscience, 2: 175-185.

Ge, B.X., Yiu, G.X., Li, C.S., 1985. A preliminary study on sedimentary environments and law of coal-bearing formation in Yangquan, Shanxi. Acta Sedimentologica Sinica, 3: 33-44.

Golonka, J., Ford, D., 2000. Pangean (Late Carboniferous-Middle Jurassic) paleoenvironment and lithofacies. Palaeogeography Palaeoclimatology Palaeoecology, 161: 1-34.

Grossman, E.L., Bruckschen, P., Mii, H.-S., Chuvashov, B.I., Yancey, T.E., Veizer, J., 2002. Carboniferous paleoclimate and global change: isotopic evidence from the Russian Platform: Carboniferous stratigraphy and Paleogeography in Eurasia. Institute of Geology and Geochemistry, Russian Academy of Sciences, Urals Branch (Ekaterinburg): 61-71.

Guo, J., Sun, G., Liu, W., 2019. Formation phases of carbonate cements and sedimentary environments in lower Jurassic sandstones of the Lenghu $\mathrm{V}$ tectonic belt, North Qaidam Basin, China. Carbonates and Evaporites, 34: 1367-1379.

Guo, Y., Liu, H., 2000. The late Palaeozoic depositional systems of Shaanxi-Gansu-Ningxia area (in Chinese with English summary). Journal of Palaeogeography, 2: 19-30.
Han, S.F., 1990. Coal-forming Conditions and Coalfield Prediction in Huaibei-Huainan Region. Geological Publishing House (Beijing): 41-65.

Hastings, D.W., Emerson, S.R., Mix, A.C., 1996. Vanadium in foraminiferal calcite as a tracer for changes in the areal extent of reducing sediments. Paleoceanography, 11: 665-678.

Hilton, J., Wang, S.-J., Galtier, J., Li, C.-S., 2001. An Early Permian plant assemblage from the Taiyuan Formation of northern China with compression/impression and permineralized preservation. Review of Palaeobotany and Palynology, 114: 175-189.

Isbell, J.L., Cole, D.I., Catuneanu, O., 2008. Carboniferous-Permian glaciation in the main Karoo Basin, South Africa: stratigraphy, depositional controls, and glacial dynamics. GSA Special Papers, 441: 71-82.

Jacobsen, S.B., Kaufman, A.J., 1999. The Sr, C and O isotopic evolution of Neoproterozoic seawater. Chemical Geology, 161: $37-57$

Jaffrés, J., Shields-Zhou, G.A., Wallmann, K., 2007. The oxygen isotope evolution of seawater: a critical review of a long-standing controversy and an improved geological water cycle model for the past 3.4 billion years. Earth-Science Reviews, 83: 83-122.

Jones, B., Manning, D.A.C., 1994. Comparison of geochemical indices used for the interpretation of palaeoredox conditions in ancient mudstones. Chemical Geology, 111: 111-129.

Kaufman, A.J., Jacobsen, S.B., Knoll, A.H., 1993. The Vendian record of $\mathrm{Sr}$ and $\mathrm{C}$-isotopic variations in seawater: implications for tectonics and paleoclimate. Earth and Planetary Science Letters, 120: 409-430.

Keith, M.L., Weber, J.N., 1964. Isotopic composition and environmental classification of selected limestones and fossils. Geochimica et Cosmochimica Acta, 28: 1787-1816.

Kimura, T., 1998. Relationships between inorganic elements and minerals in coals from the Ashibetsu district, Ishikari coal field Japan. Fuel Process Technology, 56: 1-19.

Korte, C., Kozur, H.W., Veizer, J., 2005. $\delta^{13} \mathrm{C}$ and $\delta^{18} \mathrm{O}$ values of Triassic brachiopods and carbonate rocks as proxies for coeval seawater and palaeotemperature. Palaeogeography Palaeoclimatology Palaeoecology, 226: 287-306.

Kuleshov, V.N., Sedaeva, K.M., Gorozhanin, V.M., Gorozhanina E.N., 2018. Hypostratotype of the Bashkirian stage of the Carboniferous system (Askyn River, Bashkortostan): lithology, isotopes $\left(\delta^{13} \mathrm{C}, \delta^{18} \mathrm{O}\right)$, and carbonate depositional settings. Stratigraphy and Geological Correlation, 26: 698-719.

Kump, L.R., Arthur, M.A., 1999. Interpreting carbon isotope excursions: carbonates and organic matter. Chemical Geology, 161: 181-198.

Latal, C., Piller, W.E., Harzhauser, M., 2004. Palaeoenvironmental reconstructions by stable isotopes of Middle Miocene gastropods of the central Paratethys. Palaeogeography Palaeoclimatology Palaeoecology, 211: 157-169.

Lee, Y.I., Lee, J.I., 2003. Paleozoic sedimentation and tectonics in Korea: a review. Island Arc, 12: 162-179.

Li, X-Y., Wang, S.-P., 2006. Study of the sedimentary microfacies of the Taiyuan Formation in the Tabamiao area, Ordos, China (in Chinese with English summary). Journal of Chengdu University of Technology (Science and Technology Edition), 33: 214-217.

Li, H.Y., He, B., Xu, Y.G., Huang, X.L., 2010. U-Pb and Hf isotope analyses of detrital zircons from Late Paleozoic sediments: insights into interactions of the North China Craton with surrounding plates. Journal of Asian Earth Sciences, 39: 335-346.

Lv, D.W., Chen, J.T., 2014. Depositional environments and sequence stratigraphy of the Late Carboniferous-Early Permian coal-bearing successions (Shandong Province, China): sequence development in an epicontinental basin. Journal of Asian Earth Sciences, 79: 16-30.

Mao, Y., Webster, G.D., Ausich, W.U., Li 2018. A new crinoid fauna from the Taiyuan Formation (early Permian) of Henan, North China. Journal of Paleontology, 92: 1066-1080. 
McManus, J., Berelson, W.M., Klinkhammer, G.P., Hammond, D.E., Holm, C., 2005. Authigenic uranium: relationship to oxygen penetration depth and organic carbon rain. Geochimica et Cosmochimica Acta, 69: 95-108.

McConnaughey, T., 1989. $\mathrm{C}^{-13}$ and $\mathrm{O}^{-18}$ isotopic disequilibrium in biological carbonates: II. In vitro simulation of kinetic isotope effects. Geochimica et Cosmochimica Acta, 53: 163-171.

McConnaughey, T.A., Burdett, J., Whelan, J.F., Paull, C.K., 1997. Carbon isotopes in biological carbonates. Respiration and Photosynthesis, 61: 611-622.

Mii, H-S., Grossman, E.L., Yancey, T.E., Chuvashov, B., 2001. Isotopic records of brachiopod shells from the Russian Platform - evidence for the onset of mid-Carboniferous glaciation. Chemical Geology, 175: 133-147.

Montańez, I.P., Cecil, C.B., 2013. Paleoenvironmental clues archived in non-marine Pennsylvanian-lower Permian limestones of the central Appalachian Basin, USA. International Journal of Coal Geology, 119: 41-55.

Morford, J.L., Russell, A.D., Emerson, S., 2001. Trace metal evidence for changes in the redox environment associated with the transition from terrigenous clay to diatomaceous sediment, Saanlich Inlet, BC. Marine Geology, 174: 355-369.

Neuhuber, S., Wagreich, M., Wendler, U., Spötl, C., 2007. Turonian Oceanic Red Beds in the Eastern Alps: concepts for palaeoceanographic changes in the Mediterranean Tethys. Palaeogeography Palaeoclimatology Palaeoecology, 251: 222-238.

Pailler, D., Bard, E., Rostek, F., Zheng, Y., Mortlock, R., Van Geen, A., 2002. Burial of redox-sensitive metals and organic matter in the equatorial Indian Ocean linked to precession. Geochimica et Cosmochimica Acta, 66: 849-865.

Payne, J.L., Kump, L.R., 2007. Evidence for recurrent Early Triassic massive volcanism from quantitative interpretation of carbon isotope fluctuations. Earth and Planetary Science Letters, 256: 264-277.

Pufahl, P.K., James, N.P., Kyser, T.K., Lukasik, J.J., Bone, Y., 2006. Brachiopods in epeiric seas as monitors of secular changes in ocean chemistry: a Miocene example from the Murray Basin, South Australia. Journal of Sedimentary Research, 76: 926-941.

Rosenthal, Y., Boyle, E.A., Labeyrie, L., 1997. Last Glacial Maximum paleochemistry and deepwater circulation in the Southern Ocean: evidence from foraminiferal Cd. Paleoceanography, 12: 787-796.

Ross, C.A., Ross, J.R.P., 1988. Late Paleozoic transgressive-regressive deposition. SEPM Special Publication, 42: 227-247.

Sahney, S., Benton, M.J., Falcon-Lang, H.J., 2010. Rainforest collapse triggered Carboniferous tetrapod diversification in Euramerica. Geology, 38: 1079-1082.

Sarin, M.M., Krishnaswami, S., Somayajulu, B.L.K., Moore, W.S., 1990. Chemistry of uranium, thorium, and radium isotopes in the Ganga-Brahmaputra river system: weathering processes and fluxes to the Bay of Bengal. Geochimica et Cosmochimica Acta, 54: 1387-1396.

Scheffler, K., Hoernes, S., Schwark, L., 2003. Global changes during Carboniferous-Permian glaciation of Gondwana: linking polar and equatorial climate evolution by geochemical proxies. Geology, 31: 605-608.

Schmitz, B., Charisi, S.D., Thompson, E.I., Speijer, R.P., 1997. Barium, $\mathrm{SiO}_{2}$ (excess), and $\mathrm{P}_{2} \mathrm{O}_{5}$ as proxies of biological productivity in the Middle East during the Palaeocene and the latest Palaeocene benthic extinction event. Terra Nova, 9: 95-99.

Schmitz, M.D., Pfefferkorn, H.W., Shen, S.-Z., Wang, J., 2020. A volcanic tuff near the Carboniferous-Permian boundary, Taiyuan Formation, North China: radioisotopic dating and global correlation. Review of Palaeobotany and Palynology, 104244 (in press)

Scotese, C.R., Nokleberg, W.J., Parfenov, L.M., Badarch, G., Berzin, N.A., Khanchuk, A.I., Kuzmin, M.I., Obolenskiy, A.A., Prokopiev, A.V., Rodionov, S.M., Yan, H., 2005. Tectonic and metallogenic evolution of northeast Asia: Key to regional under- standing. In: Mineral Deposit Research: Meeting the Global Challenge. Springer, Berlin, Heidelberg: 1183-1184.

Shao, L.-Y., Yang, Z.-Y., Shang, X.-X., Xiao, Z.-H., Wang, S., Zhang, V.L., Zheng, M.Q., Lu, J., 2015. Lithofacies palaeogeography of the Carboniferous and Permian in the Qinshui Basin, Shanxi Province, China. Journal of Palaeogeography, 4: 384-412.

Shen, S.Z., Zhang, H., Shang, Q.H., Li, W.Z., 2006. Permian stratigraphy and correlation of Northeast China: a review. Journal of Asian Earth Sciences, 26: 304-326.

Song, H., Hu, B., Zhang, L., Liu, S., Niu, Y., 2011. Characteristics of lithofacies paleogeography of the Taiyuan Formation sedimentary period, Henan Province (in Chinese with English summary). Acta Sedimentologica Sinica, 29: 876-888.

Song, H.-B., Wang, H., Wang, F., Guo, R.-R., Hu, B., 2016. Ichnofossils and ichnofabrics in the Lower Permian Taiyuan Formation of North China Basin. Geodinamica Acta, 28: 37-52.

Su, D.-C., Van Loon, A.J., Sun, A.P., 2016. How quiet was the epeiric sea when the Middle Cambrian Zhangxia Formation was deposited in SW Beijing, China? Marine and Petroleum Geology, 72: 209-217.

Sun, R., Liu, G., Zheng, L., Chou, C.-L., 2010. Geochemistry of trace elements in coals from the Zhuji Mine, Huainan Coal field, Anhui, China. International Journal of Coal Geology, 81: 81-96.

Sundby, B., Martinez, P., Gobeil, C., 2004. Comparative geochemistry of cadmium, rhenium, uranium and molybdenum in continental margin sediments. Geochimica et Cosmochimica Acta, 68: 2485-2493.

Tazawa, J., 2002. Late Paleozoic brachiopod faunas of the South Kitakami Belt, northeast Japan, and their paleobiogeographic and tectonic implications. Island Arc, 11: 287-301.

Tribovillard, N., Algeo, T.J., Lyons, T., Riboulleau, A., 2006. Trace metals as paleoredox and paleoproductivity proxies: an update. Chemical Geology, 232: 12-32.

Van Os, B.J.H., Middelburg, J.J., De Lange, G.J., 1991. Possible diagenetic mobilization of barium in sapropelic sediments from the eastern Mediterranean. Marine Geology, 100: 125-136.

Van Beek, P., Reyss, J.L., Bonte, P., Schmidt, S., 2003. Sr/Ba in barite: a proxy of barite preservation in marine sediments. Marine Geology, 199: 205-220.

Van Loon, A.J., Han, Z., Han, Y., 2012. Slide origin of breccia lenses in the Cambrian of the North China Platform: new insight into mass transport in an epeiric sea. Geologos, 18: 223-235.

Veizer, J., 2013. Carbonates and ancient oceans: Isotopic and chemical record on time scales of $10^{7}-10^{9}$ years. In: The Carbon Cycle and Atmospheric $\mathrm{CO}_{2}$ : Natural Variations Archean to Present (ed. E.T. Sundquist and W.S. Broecker): 595-601. American Geophysical Union.

Veizer, J., Prokoph, A., 2015. Temperatures and oxygen isotopic composition of Phanerozoic oceans. Earth-Science Reviews, 146: 92-104.

Wan, M.L., Yang, W., He, X.Z., Liu, L.J., Wang, J., 2017. First record of fossil basidiomycete clamp connections in cordaitalean stems from the Asselian-Sakmarian (lower Permian) of Shanxi Province, North China. Palaeogeography Palaeocimatology Palaeoecology, 466: 353-360.

Wang, J., 2010. Late Paleozoic macrofloral assemblages from Weibei Coalfield, with reference to vegetational change through the Late Paleozoic Ice-age in the North China Block. International Journal of Coal Geology, 83: 292-317.

Wang, J., Pfefferkorn, H.W., 2013. The Carboniferous-Permian transition on the North China microcontinent - oceanic climate in the tropics. International Journal of Coal Geology, 119: 106-113.

Wang, J., Pfefferkorn, H.W., Zhang, Y., Feng, Z., 2012. Permian vegetational Pompeii from Inner Mongolia and its implications for landscape paleoecology and paleobiogeography of Cathaysia. Proceedings of the National Academy of Sciences, 109: 4927-4932.

Wang, J., Béthoux, O., Ren, D., Cui, Y., 2019. An insect wing discovered in the Early Permian Taiyuan Formation (Shanxi Province, China). Fossil Record, 22: 23-76. 
Wang, K.Y., Yan, Y.H., Yang, R.Y., Chen, Y.F., 1985. REE geochemistry of early Precambrian charnockites and tonaliticgranodioritic gneisses of the Qianan Region, eastern Hebei, North China. Precambrian Research, 27: 63-84.

Wang, Z., Liu, J., Van Loon, A.J., Zhu, D., Qin, P., Han, Z., 2020. Slope failure on a Cambrian carbonate platform, mass-flow transitions and resulting complex deposit. Geological Quarterly, 64 (1): 3-15.

Wignall, P.B., Zonneveld, J.P., Newton, R.J., Amor, K., Sephton, M.A., Hartley, S., 2007. The end Triassic mass extinction record of Williston Lake, British Columbia. Palaeogeography Palaeoclimatology Palaeoecology, 253: 385-406.

Wu, D., Zhang, W., 2019. Geochemical characteristics of trace elements and carbon isotopes in Taiyuan Formation: a case study of Huainan Coalfield. Geosciences Journal, 23: 991-1003.

Wu, F., Chen, Z., Zhang, S.L., Ge, L., 1995. Transgressions during Permo-Carboniferous period in North China (in Chinese with English summary). Geoscience, 9: 284-292.

Yang, R., Van Loon, A.J., 2016. Early Cretaceous slumps and turbidites with peculiar soft-sediment deformation structures on Lingshan Island (Qingdao, China) indicating a tensional tectonic regime. Journal of Asian Earth Sciences, 129: 206-219.

Yang, R., Fan, A., Han, Z., Van Loon, A.J., 2016. An upward shallowing succession of gravity flow deposits in the Early Cretaceous Lingshandao Formation, western Yellow Sea. Acta Geologica Sinica, 90: 1553-1554.
Yang, R., Fan, A., Han, Z., Van Loon, A.J., 2017. A marine or continental nature of the deltas in the Early Cretaceous Lingshandao Formation - Evidences from trace elements. Acta Geologica Sinica, 91: 367-368.

Yarincik, K.M., Murray, R.W., Lyons, T.W., Peterson, L.C., Haug, G.H., 2000. Oxygenation history of bottom waters in the Cariaco Basin, Venezuela, over the past 578,000 years: results from redox-sensitive metals (Mo, V, Mn, and Fe). Paleoceanography, 15: $593-604$.

Zhang, H.X., 2017. The late Paleozoic brachiopod communities and their environmental significance from Shuiquangou, Yangquan, Shanxi Province, Inner Mongolia (in Chinese with English summary). Science, Technology and Economy, 1: 75-76.

Zhang, M.M., Liu, Z.J., Fang, S., Sun, Q.S., 2014. Sandstone composition of the Upper Jurassic Emuerhe Formation from the Mohe Basin, China. Geological Magazine, 151: 850-863.

Zhao, M.Y., Zheng, Y.-F., 2014. Marine carbonate records of terrigenous input into Paleotethyan seawater: geochemical constraints from Carboniferous limestones. Geochimica et Cosmochimica Acta, 141: 508-531.

Zhao, Y.Y., Zheng, Y.-F., Chen, F., 2009. Trace element and strontium isotope constraints on sedimentary environment of Ediacaran carbonates in southern Anhui, South China. Chemical Geology, 265: 345-362.

Zheng, Y.F., Xiao, W.-J., Zhao, G., 2013. Introduction to tectonics of China. Gondwana Research, 23: 1189-1206. 